\title{
漁村における生態系保全と環境社会システムの構造について 北海道羅臼町を事例として
}

\section{Study on ecosystem conservation and eco-social system strucutre in the fishing village} Case study for RAUSU Town in Hokkaidoh

児玉いずみ*・小山康吉**・長野章*** ・田三次*

Izumi Kodama, Koukichi Koyama, Akira Nagano, Sanji Kida

\begin{abstract}
This study deals with the fishing village in terms of an eco-social system representing a social mechanism in which natural environment and human society are integrated together, and aims at making its structural clarification.

Rausu Town was selected as subject for this study and the due analysis was conducted based on the available date and the questionnairing. As a result, the following points have been proved and clarified in conclusion ;

(1) Recognition that wildlife becoming even an indicator for natural environment conservation is also important in the industry and human life.

(2) Reciprocity among nature, the industry and human life by benefit from nature and regulation of industry and human life.

(3) Reduction of the industry and life of fishing village by ecosystem conservation.

(4) Assessment criteria on the value as reduced by ecosystem conservation to human society, taking into account the clarified solution of above - mentioned (3) .
\end{abstract}

Keywords : eco-social system, regulation and conservation, the value of ecosystem conservation

1. 研究の目的

漁業は海の生態系の中では漁獲という形で食物連鎖の各段階に参加しており、漁村は漁業を生業としているの で、何らかの形で森林や河川等の陸域を含む沿岸域の生態系の一部を構成している。したがって、漁業を基盤と している漁村において生態系保全を考える場合は、産業や生活といった人間の社会を含めた、環境社会システム として捉えていかなければならない。そのためには、漁村における産業や生活が、自然環境とどのような相互関 連を持っているかを明らかにする必要がある。

本研究汢、漁村の環境社会システムの構造を解明することを目的とする。具体的には北海道の羅臼町を事例と して、産業と生活と自然の相互関連の構造を分析し、生態系保全が漁村の産業や生活に還元される仕組みについ て考察した。さらに、生態系そのものの価值や、生態系保全が漁村社会にもたらす価值について、その評価法を 検郡した。

羅臼町を事例とした理由は、自然環境が良く、漁業活動が活発で、遡河性・降海性の魚類等が棲息する河川が あり、既存資料が豊富な地域であることによる。

\section{2. 漁村社会と生態系の関連の概念}

漁業沈沖合域及び沿岸域における生物群集からなる生態系内の食物連鎖（物質循環）の一部を採捕することで ある。したがって、漁業注生態系の各段階の生物に共生権を、連鎖が継続する上ゔ永続性を、すべてを捕り尽 くすことのないよう有限性を認め、採捕が安定的かつ継続的に可能な状態を保持すること（最大持続生産量）に より保障される。すなわち、漁業を生業として成り立っている漁村における人間社会は、沖合域や沿岸域の生態 系に依存し、沖合域や沿岸域の生態系を保障することで保たれているので、漁村において生態系を考える場合、 人間社会をも含めた範囲での生態系を考えなければならない。そうでないなら、漁村は一方的な漁獲（乱獲）と 言う生態系の破壊行為によって存在すると考えられてしまう。 したがって漁村という人間社会の安定は生態系の安定に依存し ていることを認識する必要がある。

図 $2-1$ は、沿岸域の環境つまり、水産生物が棲息する環境 や、その結果としての生物（資源）を利用することで、漁業と いう産業が成り立ち、生活の豊かさが得られる一方で、その㕍 業や生活を守るために、産業活動や生活を何らかの形で規制す ることによって、結果的に環境を保全しているという、産業・

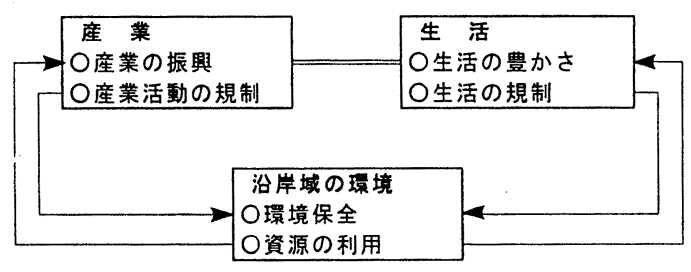

図 2-1 漁村の産業·生活·環境の相互関連

\footnotetext{
* 正: 会員

（財）漁港漁村建設技術研究所（101 丘代田区内神田1-14-10)

** 非会員（株）エコニクス

***正会員水産庁漁港部防災海岸課
} 
生活・環境の相互関連すなわち、環境社会システムの構造を示している。

\section{3. 羅臼町の概況}

$3-1$. 羅臼町の自然と産業

(1) 羅的町の自然

羅曰町は北海道東の知床半島の東南側に位置し、羅臼漁港を中心とする地区に産業及び人口集積がある。羅臼 漁港周辺の自然環境の状況 (1) は、人工度は 1 、地形の多様性は 4、自然の多様性は 2 であり、絶滅危惧種のオジ ロワシ、危急種のオオワシ、希少種のトドが一過性で棲息し、特にワシ類は昭和57年ころから急激に増加し 200 羽〜 1000 羽が飛来している。また、知床半島先端付近には絶滅危惧種のシマフクロウとヒグマが棲息している。

(2)羅臼町の産業

羅臼町の産業汇就業者数から見ても産業別生産額から見ても漁業、水産加工業、卸・小壳業、観光の 4 産業が 大宗を占めている。町全体の就業者数 4533 人の内、漁業就業者 2172 人（47.9\%）、製造業（水産加工業） 412 人

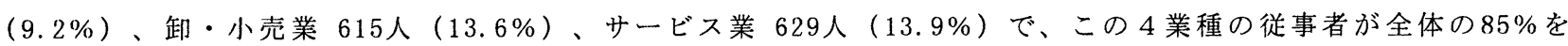
占めている。また生産額から見ても、漁業 147 億円 $(35 \%)$ 、水産加工業 113 億円（27\%）、卸・小売業 143 億

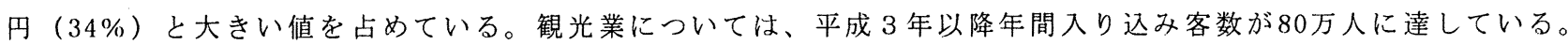
観光客の入り込みは夏季中心であるが、近年流水やオジロワシ観察の観光も増加している。

漁業生産は昭和 50 年代初期以降増加の一途を辿り平成 2 年には生産額が 250 億円、生産量は15万トンを記録し た。これらの推移はスケソ漁の増加に依るもので、スケソ漁が減少すると全体の漁獲量も漁獲金額も急激に減少 している。また、漁獲金額の中ではスケソの他、サケとコンブの金額がかなりの額を占めている。

昭和 50 年代初期以降スケソ漁が急激に伸び、さらに羅 且町全体の漁獲量が増加したのは、スケソ漁を行ってい るスケソ刺し網漁の漁船が鋼船化した時と期を一にして いる（図 3-2）。また、羅臼町の漁獲金額全体がそれ より少し早い時期に増加したが、サケの漁獲増とそれを 可能にしたサケ稚魚健苗放流尾数の大幅増加によるもの である。また近年の増養殖事業として、コンブ大規模増 殖場、築磯事業等によるコンブ增殖や、育成管理技術の 確立によるコンブ養殖が進められてきた。すなわち羅臼 の漁業の大宗を占めているスケソ、サケ及びコンブは、 それらの生産量を増加させる人為による何らかの行為の 結果といえる。

(3) 野生生物の状況と産業との関倸

ワシ類とトドは秋の終わりから冬季にかけて羅臼に来 る。これらの餌は河川に遡河するサケ、マス類と冬季に 産卵回遊するスケソであると言われている。その結果流 水とともに飛来するワシ類はスケソ漁し有無と深い関係 がある。

図 3-1にスケソの漁獲量とワシの飛来数をプロット した。図に見るようにスケソが増加するとワシの飛来数 が增加している傾向が窥える。スケソ漁が増加すると口 シ類の慨となる漁船からこぼれるスケソが多くなりワシ 類の餌が增える。ワシが飛来するには、生活環境および 繁殖場所として水辺と樹林帯が必要不可欠であるが、羅 臼町ではこのような環境が正常に機能していることを前 提にスケソという餌の増加がワシの飛来数を増加させて いることが見て取れる(2)。

ワシ類と同じょうにトドもスケソを餌としていること、 スケソ漁の多塞が流水日数と漁船の鋼船化と関連がある ことから、図 $3-2$ にワシの飛来数、トドの捕獲数、流 水日数と漁船の鋼船化の推移を同時に示す。漁船の鋼船 化とスケソの漁獲量およびワシの飛来数は増減の傾向が ほぼ一致している。トドは1991年までは捕獲数が羅臼へ

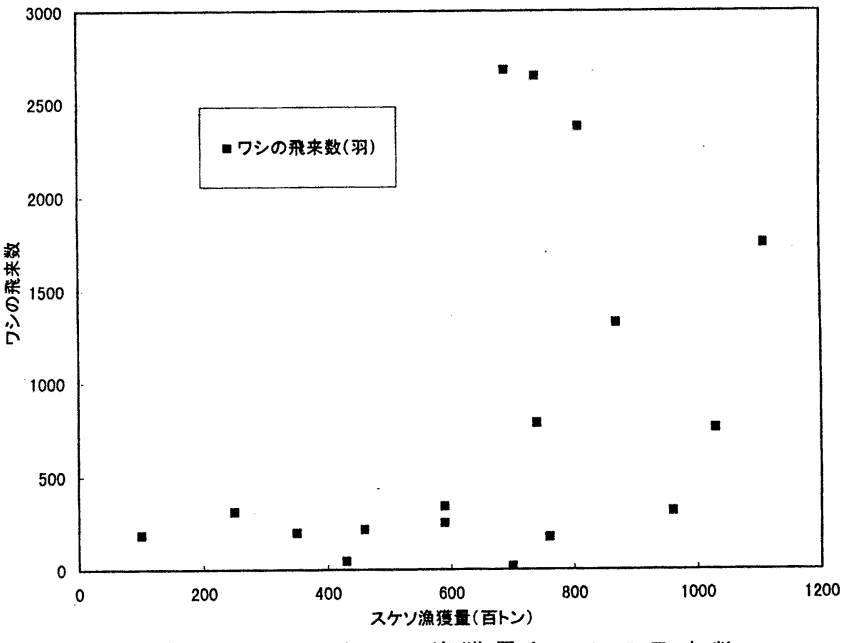

図 3-1 スケソの漁獲量とワシの飛来数

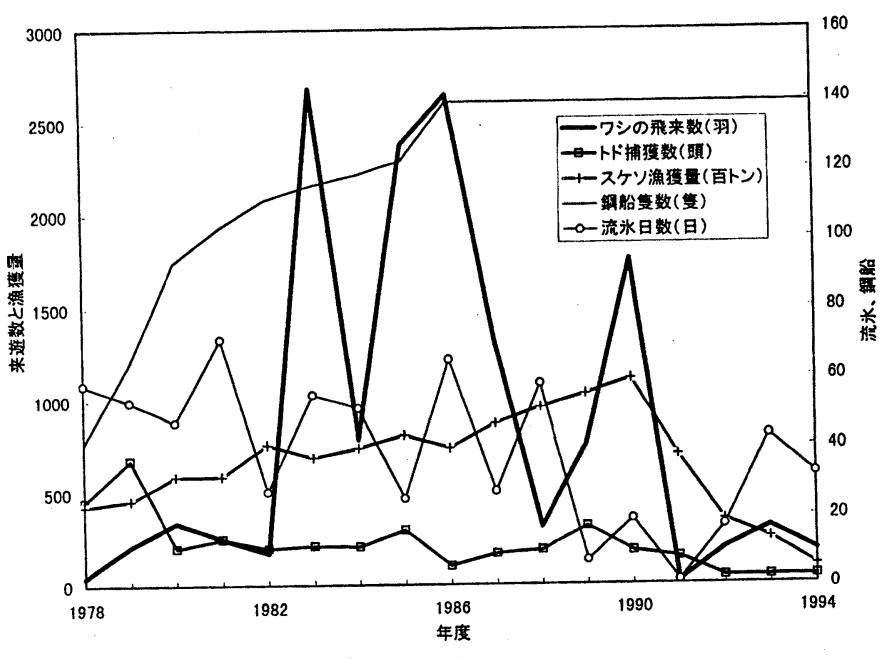

図 $3-2$ ワシ・トト・・竹数と流水日数、鋼船化の推移 
の来遊数を反映していたが捕獲枠が許可制になり、現在は来遊数を反映していない。

野生生物の産業への影響において、羅臼町における大きな産業である観光との関連を見る。羅臼町の観光は、 野生生物の棲息を誘客の大きな因子と考えている。観光への個別野生生物等の利用度を観光パンフレットから見 ると、パンフレットへの記載は、ワシ類は $100 \%$ 、海獣類や流水、植物、山や海の景観は $80 \%$ 、温泉やコンブの加 工品注 $60 \%$ となっており、これらから推察すると自然、特に野生生物を誘客物に考えていることが窥える。

以上から、羅臼町では漁船が鋼船化し流水の海で操業できるようになってからスケン漁が増加し、スケソ漁の 落ちこ㞦を餌とするワシ類の飛来数が増加した。さらにスケソを慨とするワシ類及びトド等の野生生物を誘客 物として観光産業に利用している。つまり、自然（流水）と人間の生産活動（漁業）が密接に関連し、その結果 がワシ類やトドの希少生物の棲息状況に密接に関連するとともに、その棲息が人間の生産活動（観光）に還元さ れている図式が見て取れる。

\section{$3-2$. 自然に対する住民意識}

産業や生活と野生生物との関わり合い方を明らかにするためには、実際にその地域に暮らす人々が自分たちの 生活と周囲の自然や野生生物との関わりについてどのような認識を持っているかということを明らかにする必要 がある。そこで、羅臼町の住民に対してアンケート調査を行った。対象は羅臼町の住民 127 名で、内漁業者（自 営漁業及び漁業雇われ) が61名 $(48.1 \%)$ と約半数を占めている。

（1）野生生物への思い

羅臼に棲息する主な野生生物に対する住民の意 識をまとめると、図 $3-3$ のようになる。自然の シンボルとしては、オジロワシやオオワシ $74.8 \%$ 、 シマフクロウ $48.8 \%$ 、オショロコマ39.4\%、以下 ヒグマ、海獣類が続く。町の産業・生活・環境全 般において大切な生物としては、オジロワシやオ オワシ $87.4 \%$ 、シマフクロウ $63.0 \%$ 、オショロコ マ52.0\%、以下海獣類、ヒグマが続く。いずれも、 オジロワシやオオワシ、シマフクロウという大型 の鳥類が上位に挙げられているが、これらは近年 羅臼の観光の目玉の一つともなっており、マスコ ミに取り上げられることも多い。羅臼町では、こ れらの野生生物が町のシンボル的存在として観光 等の産業を通して生活に関わっているという認識

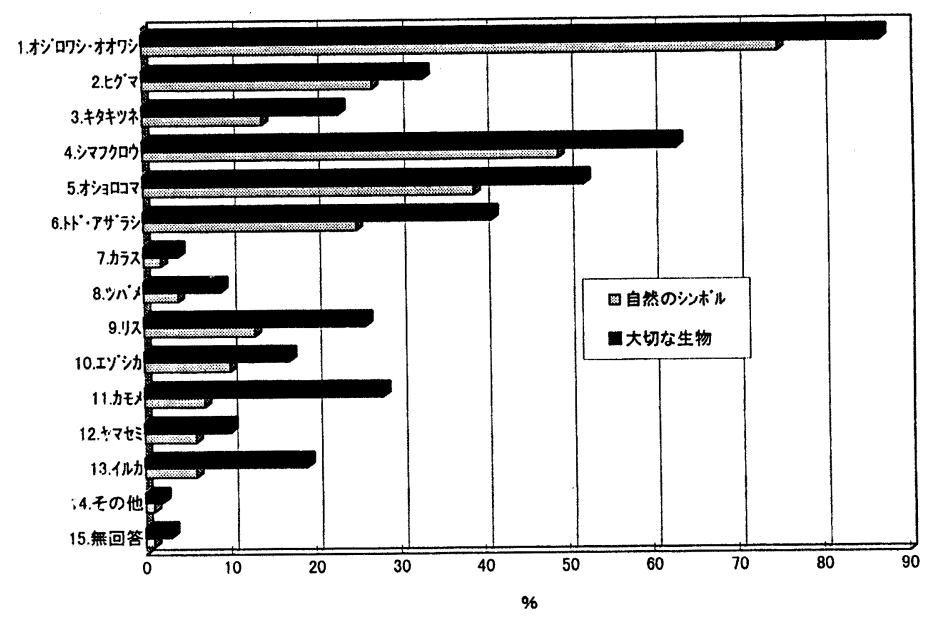

図 3 -3 野生生物への思い と、これらの野生生物の存在が羅臼の自然環境を 基盤としているという意識が強く持たれていることの表れである。

(2) ワシと漁村社会

羅曰にとって、自然や産業・生活にとってシンボル的な存在となっているワシをとりあげ、ワシによる産業、 生活、自然環境への影響と、ワシを守るための産業、生活の規制及び自然保護活動について設問した結果は、図 $3-4 、 3-5$ の通りである。

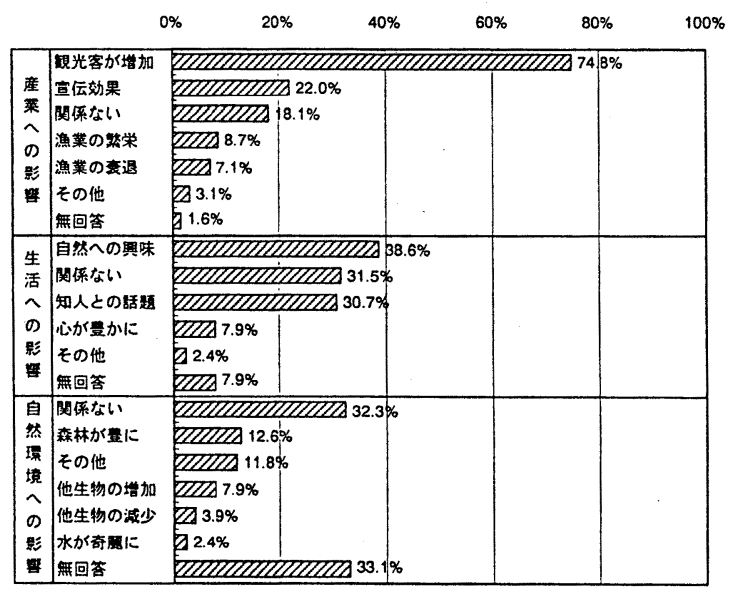

図 3-4 ワシが漁村社会に与える影響

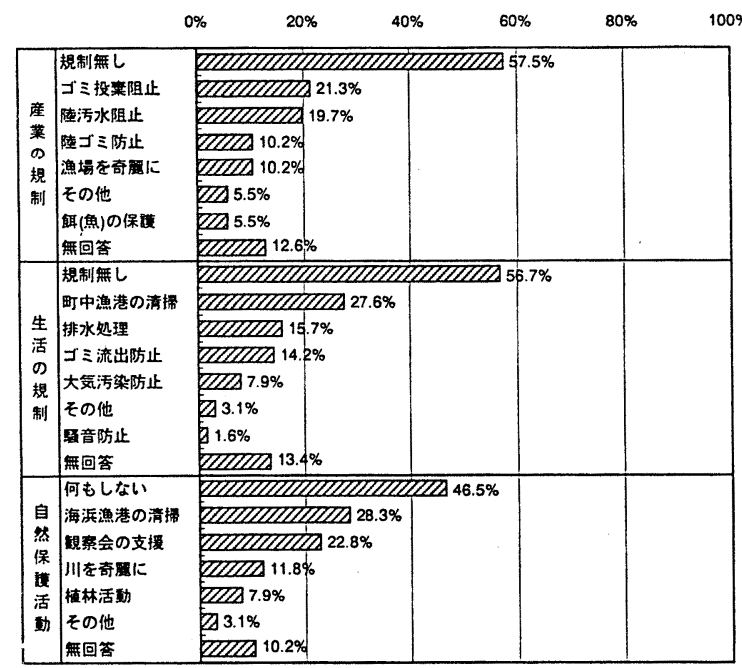

図3ー5 ワシを守るための規制や保護活動 
ワシによる産業への影響としては、74.8\%の人が「観光客の増加」を挙げ、次いで「羅臼の宣伝効果」が挙げ られており、観光という産業にとってのワシの位置付けが確立していることが解る。ワシによる生活への影響と

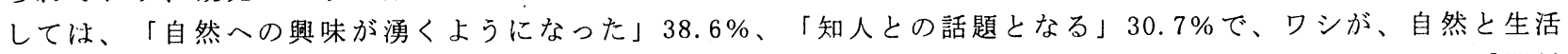
や人間同志のコミュニケーションの媒介となっているここが窥える。ワシによる環境への影響としては、「関係

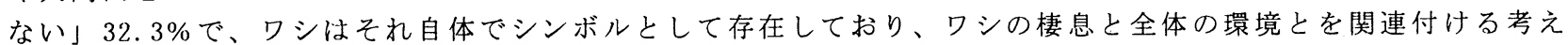
方は、人ぬの意識の中ではまだ明確になっていないことが窥える。ワシを完るために行っている産業や生活の中 での規制や自然保護活動については、いずれも「特に何もしていない」とする回答が最も多かった。

$3-3$ 、規制による環境保全

図2-1に示した通り、人間は自然の資源を産業や生活のた めに利用し、漁業を成立させ生活の豊かさをもたらしている。 一方で、その利用が継続するために、人間は環境の保全を行う が、自然保護活動のような直接的な形だけでなく、産業面や生 活面での様々な規制と言う形で表れる。羅臼町において、環境 保全のために実際にどのような規制が行われているのかをまと めたのが表 3 - 1 である。

4.生態系の保全と社会システム

4 - 1. 羅臼町の環境社会システム

これまで、羅臼において人々が如何に自然を利用し、また、 それを守るためにどのような規制を行っているかを見てきたが、 このような活動を通して産業・生活・環境の間の相互関連が組 み立てられ、その仕組みが羅臼の環境社会システムとなってい る。この環境社会システムを構成する要素は、羅臼の様々な環 境や生物や人間活動であり、これら全ての関わりについて把握 することは不可能なので、ここでは、アンケート結果より、自 然のシンボルとしてまた、産業や生活にとっても大切な生物と して認識されているワシを取り上げ、ワシを軸とした羅臼町の 環境社会システムがどのような仕組みになっているかを考察す る。図 4-1 はワシとそれを巡る人間の諸活動を整理すること で、羅臼の社会と環境の相互関連の具体的なモデルを構築する ことを試みたものである。

羅放の環境社会システムをワシを軸として整理すると（表 $4-1$ ) 、産業とワシとの関係では、多くの人がワシが観光 客の増加に影響している、あるいは、観光資源となっている と認識しており、ワシの観察会等の新たな活動や、マスコミ による宣伝効果で羅臼が有名になる等、ワシが羅臼の観光を 中心とする産業面に及ぼす影響猅常に大きくなっている。 また、生活とワシとの関係を見ると、ワシが余所の人とのコ ミュニケーションの媒介となっていたり、ワシを通じて羅臼 の自然への興味が湧く等、生活の豊かさを生み出すもの、生 活と環境とを結びつけるものとしてワシの影響が大きいこと が解る。一方、ワシが棲息しているということは、羅臼では ワシを頂点とする生物の種の多様性が保たれているというこ とであり、ワシが羅臼の自然を計る一つの基準となっている ことが解る。

このように、ワシの存在は羅臼の環境の状態を表徵してお り、ワシの存在そのものが羅臼の生態系にとって重要な意味 を持つ。同時に、人間がワシを利用することで、産業の振興 や生活の豊かさに大きな影晦を及ぼしており、このことを認 識寸ることで、人間は様々な規制活動を行いワシを保護しよ うとする。そのためには、ワシの棲息に必要な環境全体を考
表 3ー1 羅臼町における規制の一覧

\begin{tabular}{|c|c|c|c|}
\hline & 制 & 主な対象事項 & 規 制 の \\
\hline 漁 & 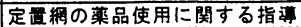 & 海 域 保 全 & 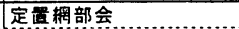 \\
\hline 業 & 海底清㛿 & 海域保全 & スヶソ部会 \\
\hline の & 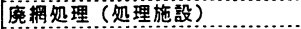 & 海域保全 & 町 (管理) \\
\hline 規 & 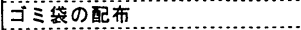 & 海域保全 & 漁劦 \\
\hline 制 & 雜草聶除 & 漁場整僺 & 漁業者(コンプ・ウ二漁) \\
\hline & 滨嫦除 & 海 浜 保 全 & 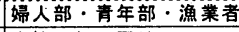 \\
\hline 他 & 重れ流し防止協定 & 海域 保全 & 漁協 - 加工団地 \\
\hline の & 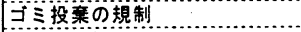 & 海域保全 & 町 \\
\hline 産 & 公園の清㛿 & 陸 域 保 全 & 町（国立公園を \\
\hline 業 & 熊，湯の清揭 & 陸 域 㷛全 & 十る会! \\
\hline の & 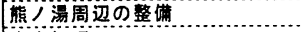 & 陸域保全 & 焦民・キャンプ客 \\
\hline \begin{tabular}{|l} 
規 \\
制
\end{tabular} & 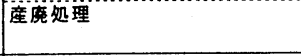 & 陸域·海域保全 & 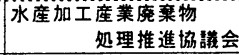 \\
\hline 生 & $\exists ミ$ ヨ分別 & 㻴境保全 & 町 (条例) \\
\hline 活 & 合僧浄华橧 & 海域保全 & 町 (指導) \\
\hline の & 家庭排水满へのネットの使用 & 河川!海域保全 & 隹民：町内会 \\
\hline 規 & 合成洗削の使用規制 & 河行海域保全 & 焦民(自主的活動) \\
\hline 制 & 家鷹コの海への投莗の規制 & 海 域 保 全 & 住民（自主的活勲） \\
\hline & 河i & 河川・海域保全 & 町内人会 \\
\hline
\end{tabular}

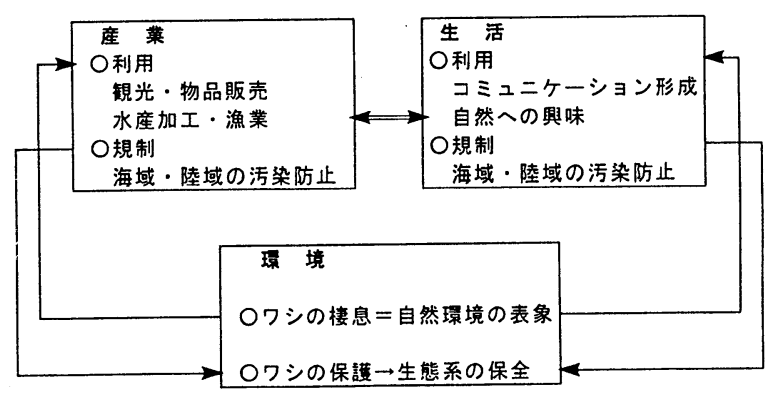

図4-1 ワシと漁村社会の相互関連

表 4ー1 ワシを軸とした羅臼の

噮境社会システムの楧成

\begin{tabular}{|c|c|c|c|}
\hline & & ワシを軸とした胃に & 町 क 成り立 5 \\
\hline & & ワシから得るもの & 規制すること \\
\hline & & ○テータより & Oアンケートより \\
\hline & & 生 スケン漁獲量とワン杂来数との相関 & 特に規制していない(58X) \\
\hline $\begin{array}{l}7 \\
\text { シ }\end{array}$ & 社 & ○アンヶートより & コミの投裹を止める(21K) \\
\hline を & & 钼光客の墙加 (75\%) & 污水を出さない(20\%) \\
\hline 軸 & 会 & 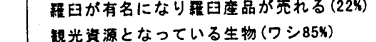 & \begin{tabular}{|} 
Oヒアリングより \\
海域、海浜、淕䭪の保全
\end{tabular} \\
\hline と & シ & 利共がある生物 (ワシ32x) & \\
\hline す & & ○ヒアリングより & \\
\hline $\begin{array}{l}\text { る } \\
\text { 羅 }\end{array}$ & $\pi$ & ワシの洋上银察会の实施 & \\
\hline 萑 & & ワシから得るもの & 規制すること \\
\hline (1) & $\bar{\tau}$ & 生 ○アンケートより & ○アンヶートより \\
\hline の & & 自然への睘味が㴗く(395) & 特に規制していない(57K) \\
\hline 環 & ム & 知人や瞡成との話题になる & 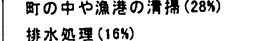 \\
\hline 隚 & & 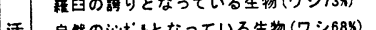 & $\begin{array}{l}\text { 排水処理(164) } \\
\text { ○ヒフリングより }\end{array}$ \\
\hline 会 & & 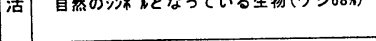 & 海㳦、海浜、陸域の保全 \\
\hline シ & & ワシから得る環境 & 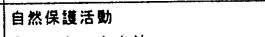 \\
\hline ス & 㻴 & Оデータより & ○アンケートより \\
\hline $\bar{\tau}$ & 境 & スケソの消㨦とワシの舟来数の相関閣係 & 特に何もしていない(47א) \\
\hline$\Delta$ & シ & Oアンヶートより & 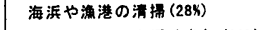 \\
\hline & $\pi$ & 自然が守られている目安になる生物 (ワシ75\%) & 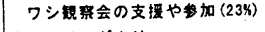 \\
\hline & $\bar{\tau}$ & 减少している生物 (ワシ42K) & ○ヒアリングょり \\
\hline & ム & & 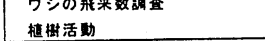 \\
\hline
\end{tabular}


えなければならないので、ワシの保護は最終的には環境全体の保全へつながっていく。

$4-2$. 野生生物と環境社会システム

ワシ類は羅臼町の自然の表徵であり、生態系ピラミッド において上位に位置している。ワシ類の生活環境は、餌場 として河川や海などの水辺にかなり依存しており、また、 塒や繁殖場所として樹林帯などは必要不可欠な環境である。 餌場を水辺に依存する魚食性の鳥類であるため、このよう な生活環境が正常に機能しなければ、ワシ類が生存してい くことは難しい。またワシ類は、陸域から海域にかけての 魚類を中心に餌とし、その他に中型鳥類や肉食哺乳類など を餌としている。これらのワシ類が棲息するための環境要 素は、保水、土砂流入防止、環境浄化や河川之沿岸に栄養 補給をし、慨としての動物の生存を可能にする。

これら環境要素の機能は、森林の保全により災害防止や 自然景観の維持がなされ、沿岸の環境の安定や維持をする 事で間接的に水産資源に寄与するものである。また、ワシ

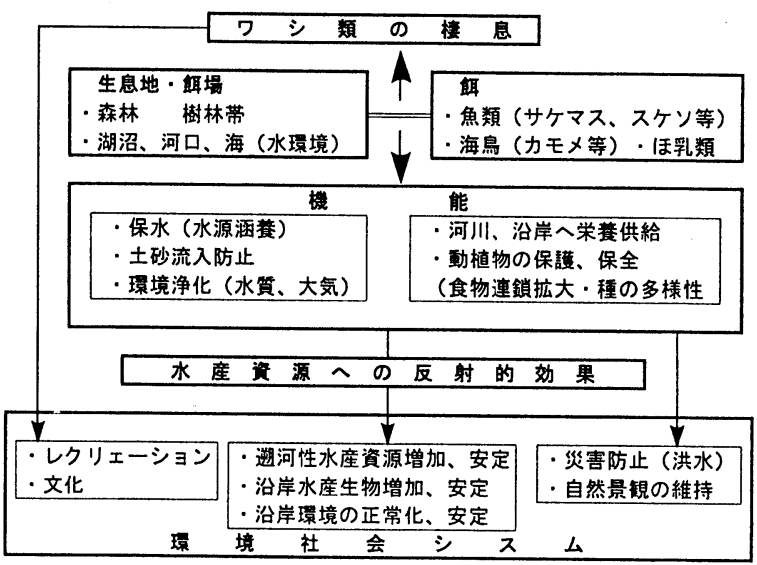

図4-2 ワシの保全の

環境社会システムへの還元 ヨンや文化の面へも奇与している。そして各々の機能注水産資源への直接的、あるいは反射的効果として、大き な意味での環境保全機能となり、食物連鎖網の拡大寸なわち漁業対象生物の拢大に繋がる。以上のワシ類の保全 が環境社会システムによ゙の様に還元されるのかを図 $4-2$ に示す。

$4-3$. 生態系保全の評価法

(1) 評価の枠組み

羅臼町の生態系の保全注、 漁業、水産加工業および観光 業を成立させており、生態系 を保全寸るため産業活動に規 制がなされる。生活について も、生態系の保全が生活の豊 かさに寄与しており、その生 活の䅱かさを守るため生活に 規制がなされる。さらに、生 態系㳉これら上記の産業およ

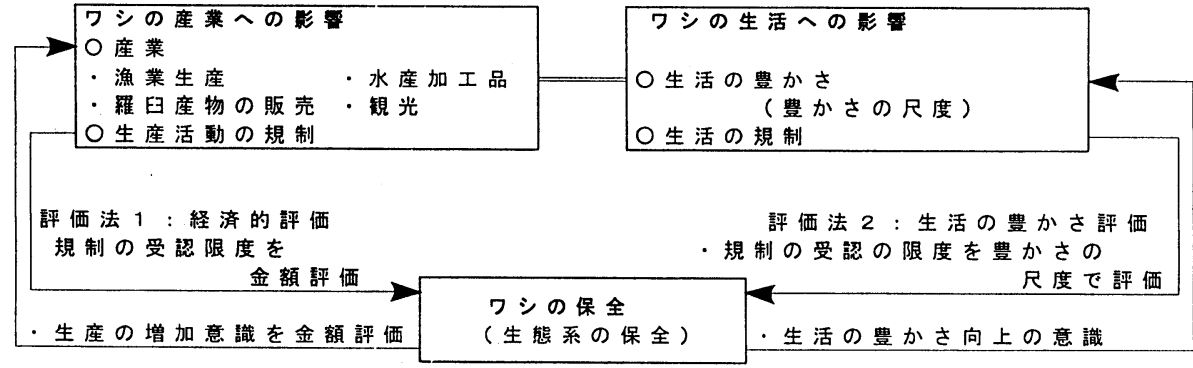

図 4ー3 ワシを軸とする環境社会システムの評価

び生活のためにあるばかりでなく、本来的に生態系そのものに価值がある。

ワシ類㹥生態系ピラミッドの上位に位置するのでワシ類の保全を生態系全体の保全に置き換えて考える。生態 系の保全の評価はワシ類の保全の評価である。そしてそれはワシを軸とする環境社会システムの評価であり、産 業、生活及び自然環境の側面から評価がなされる（図4-3）。

(2) 生産活動への評価

生態系の保全を行うし、漁業、水産加工業肪よび観光業り経済活動に対して得るものがある。このことはアン ケート調査からも明確に出ており（図 $3-4$ ）、これらは産業活動であるから得るものは金額換算できる。金額 換算の方法は産業が得る面からと、生態系保全のために産業がその活動をどこまで規制できるかの雨面から行う ことができる。

(3) 人間の生活豊かさへの評価

ワシ類の棲息が羅臼町の生活を豊かにしているという効果があることは、アンケート調査からも示されている (図 $3-4$ )。またそのためには生活に規制を加えてもいいという人も多い。この生活の豊かさが設定されると、 この尺度において向上の度合いと向上のためには生活の規制をどこまで受認できるかの二面で評価が可能である。

(4) ワシ類の保全の絶対的評価

生態系の保全の絶対的評価は既存の研究においても結論を得ていないが、生物多様性が評価の大きな基準であ ることは知られている。ワシ類の棲息は羅臼町における食物連鎖の拡大の結果であり、種の多様性の結果である。 したがって、ワシ類の保全の生態学的な評価は、ワシ類の保全によってどれくらい食物連鎖と種の多様性が拡大 したかを評価すればよい。 
5：おわりに

環境社会システムは、特定の生物のみによって説明できるものではなく、海域や陸域に棲息している様々な生 物や、地形、気象等と、人間の諸活動が相互作用をもって構成されている。しかし、それら全ての相互関連につ いて解明すること山不可能である。本研究では、ワシと人間社会との関わり方の構造を分析することで、環境社 会システム全体の仕組みを見ようとした。したがって、ここで取り上げている「ワシ」は環境を表徵する生物と いう位置付けにある。

今後江生態系保全の評価を検討するために、表徵生物としてのワシを軸とする環境社会システムの評洒法を検 畎していく。

参考文献

（1）児玉いずみ：漁港周辺の生態系保全の状況と生態系に配慮した漁港漁村整備方式について 沿岸開発と生態系保全講演論文集, ppA-10、平成 8 年 9 月

（2）森岡照明ら：図鑑 日本のワシタカ類 文一総合出版, 1995 